\title{
Adaptation of imported goats to the natural climate conditions of Uzbekistan
}

\author{
I Eshmatov ${ }^{1}$, Sh Eshmatova ${ }^{1}, M$ Eshmatova $^{1}, B$ Davronov $^{1}, K h$ Donayev $^{2}, U$ Soatov ${ }^{2, *}$, \\ and $C h$ Toshpulatov $^{3}$ \\ ${ }^{1}$ Livestock and Poultry Research Institute, Tashkent, Uzbekistan \\ ${ }^{2}$ Tashkent State Agrarian University, Universitetskaya str., 2, 100140, Tashkent, \\ ${ }^{3}$ Tashkent Branch of the Samarkand Institute of Veterinary Medicine Tashkent, Uzbekistan
}

\begin{abstract}
This research was intended to determine clinical signs and morphological features of blood in the adaptation of imported goat breeds in dairy farming to local climatic conditions, and to establish the formation of new farms in Uzbekistan. The analysis of the clinical condition of the goats during the study showed that changes in weather temperature during the seasons also affected their heart rate. The average heart rate of males in the summer was 63.3-63.5 times, respectively, in the spring - 63.3-63.9 times, in the winter and autumn, it was 63.3-63.4 times. Although there were differences in the respiration of the heifers because of the seasons and their age, they remained at the level of the physiological norm. When the body temperature of young females was observed in the winter, spring, summer and autumn, in the summer, the daytime temperature was 0.4-0.7 ${ }^{\circ} \mathrm{C}$ higher than the morning temperature, and in the evening the air temperature decreased again. The body temperature of young females averaged $39.2{ }^{\circ} \mathrm{C}$ in groups in summer, $38.8{ }^{\circ} \mathrm{C}$ in spring, $38.9{ }^{\circ} \mathrm{C}$ in autumn, and $39.0{ }^{\circ} \mathrm{C}$ in winter. Clinical cases of young goats were observed during the study.
\end{abstract}

\section{Introduction}

Increasing the production of agricultural products and increasing the economic income of the rural population play an important role in improving living standards of the population. In recent years, there has been a growing interest in dairy farming by landowners, farmers and ranchers. The dairy industry in Uzbekistan is a new direction, and dairy breeds are being imported from European countries [1-3]. Application of imported high-yielding goats and purebred breeding methods in their offspring, especially in purebred breeding and scientific substantiation of milk yield indicators of the offspring of the founders of the new in-breed system and selection of high-yielding selection groups from their offspring. The creation of a new system of selection and generation of families is the main content of the selection work [7-9]. An introduction of imported Zaanen, Alpine, Toggenburg, AngloNubian goats in purebred breeding, preservation and reproduction of their offspring as purebreds, the use of innovative methods of care and feeding bring high economic benefits

*Corresponding author: soatov1978@mail.ru 
from the dairy industry $[3-5,10]$. Effective use of imported goats in selection work, breeding of goats as purebreds, maintaining their number, obtaining many offspring, ensuring the manifestation of their productivity traits, development of scientific and practical bases in selection are important in the dairy industry. Of the total number of goats in the world, $60.4 \%$ are in Asia and $33.7 \%$ in Africa. The adaptation of goats to different natural climatic conditions in the wide distribution and the effective use of selection and selection methods in their selection in terms of productivity are important in the development of the industry [11].

In goats, the period of sexual arousal lasts more than 48 hours, that is, the duration of the sexual period varies from 4 to 26 days, their average sexual period is 17-19 days. In them, the duration of the gestation period averages 150 days. In the natural climate of Uzbekistan, dairy goats are slaughtered in the same way as other goats in the autumn, in September-November, for 30-45 days, either naturally or artificially [5-7]. Mother goats and ewes that have reached the age of lambing are weaned at least $75 \%$ in the first and second decade of the lambing season [14-15]. Calf goats give birth mainly to one or two, rarely three or four, or 1 to 3 percent of the goats in the herd give birth to twins. The duration of use of goats in farm production is 7-8 years. Some hereditary traits use goats with high productivity and strong constitution on the farm for 8-10 years [8].

Adaptation of dairy goats imported from Europe to the natural climatic conditions of Uzbekistan, as well as the rational use of high-yielding heifers and mother goats in the selection work are among the urgent tasks in the formation of the dairy industry. In order to modernize agriculture and breeding sector, the Decree of the President of the Republic of Uzbekistan PF-4947 "On the Strategy of Actions for Further Development of the Republic of Uzbekistan" was adopted [1]. Locally bred goats produce an average of 180-200 kg of milk, $13-15 \mathrm{~kg}$ of meat, $2.0 \mathrm{~kg}$ of hides and up to 1.0 tons of organic fertilizer per year and are widely used in agriculture and industry. Goat's wool and tweed are widely used in the textile light industry. Goatskins are used to make leather products and other valuable leather raw materials. Additional products obtained from the slaughter of goats - blood, bones, horns and wool are used for industrial purposes. Goat's milk contains nicotinic acid, which is useful for cardiovascular and nervous diseases. Goat's milk is closer to women's milk in terms of its chemical composition [3-5]. Milk contains $3 \mathrm{~g}$ of protein or $12 \mathrm{kcal}, 4.2$ $\mathrm{g}$ of fat $38 \mathrm{kcal}$ and $4.5 \mathrm{~g} 18 \mathrm{kcal}$ carbohydrates $4.5 \mathrm{~g} 18 \mathrm{kcal}$, or their proportion in milk are $57 \%, 27 \%$ and $18 \%$, respectively. The capacity of $100 \mathrm{~g}$ of goat's milk is $66.7 \mathrm{kcal}$. Goat's milk contains valuable macro and micronutrients such as calcium, magnesium, iron, manganese, potassium. Goat's milk is also rich in fat and protein [12-13]. Goat's milk is quickly and easily digested by the human body, and the fat grains of milk are twice as small as the fat grains of cow's milk. This research was intended to determine clinical signs and morphological features of blood in the adaptation of imported goat breeds in dairy farming to local climatic conditions, and to establish the formation of new farms in the country.

\section{Materials and methods}

"Agro Zangiota" in Yangiyul district of Tashkent region, "Alisher Chorvador" in Kibray district, "Naslli kumush kurka" in Syrdarya district of Syrdarya region, "INZIM TEX" LLC, and "Bakht Imkon Chorvo Rivoji" in Altynkul district of Andijan region in Uzbekistan were selected as study sites in this research. Of the heifers in the herd, three pedigree heifers’ №532903, №656808 and №837122 were selected for the research [2, 3, 9-12].

Zootechnical, biological and statistical methods were used in the research. Clinical and hematological parameters of goats were determined according to the method of A.A. 
Kudryavtsev (1974) and A.A. Vasilev (1968). All data obtained in the study were processed biometrically using the method of E.K. Merkureva (1970) [4-7].

\section{Results and discussion}

When dairy goats imported from abroad adapted to the natural climatic conditions of Uzbekistan, it was observed that it was a bit difficult for them to adapt to the conditions of keeping and feeding. It was found that there is a significant difference between the humid climate of European countries and the dry hot climate of Uzbekistan. Furthermore, changes in the clinical conditions and morphological features of the blood of imported goats, as well as physiological conditions in the morning, afternoon and evening, were observed.

In winter, spring, summer and autumn, the temperature in the foothills was $0.4-0.7^{\circ} \mathrm{C}$ higher than in the morning, and in the evening, the temperature was dropped again. The body temperature of the bucks averaged $39.2^{\circ} \mathrm{C}$ in groups in summer, $38.8^{\circ} \mathrm{C}$ in spring, and $39.3^{\circ} \mathrm{C}$ in winter and autumn, or a partial decrease in body temperature was observed as the air temperature decreased. The analysis of the clinical condition of the goats during the study showed that changes in weather temperature during the seasons also affected their heart rate. The average heart rate of males in the summer was 63.3-63.5 times, respectively, in the spring - 63.3-63.9 times, in the winter and autumn, it was 63.3-63.4 times. Although there were differences in the respiration of the heifers because of the seasons and their age, they remained at the level of the physiological norm. The respiration rate of the heifers averaged 31.3 beats per minute in the summer, followed by 27.5 times/minute in the spring and 31.7 times/minute in winter and autumn (Table 1).

Table 1. Seasonal clinical indications for breeding heifers.

\begin{tabular}{|c|c|c|c|c|c|c|c|c|c|}
\hline \multirow{3}{*}{ Groups } & \multicolumn{3}{|c|}{ Morning } & \multicolumn{3}{|c|}{ Afternoon } & \multicolumn{3}{|c|}{ Evening } \\
\hline & 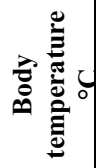 & 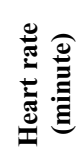 & 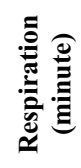 & 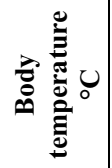 & 氖 & 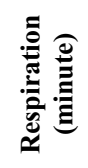 & U & 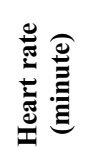 & 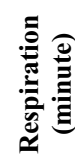 \\
\hline & $\Sigma \Xi$ & $\Sigma \Xi$ & $\Sigma \Xi$ & $\Sigma$ 者 & $\sum \Xi$ & $\Sigma$ 茾 & $\sum \Xi$ & $\Sigma$ 茾 & $\Sigma \Xi$ \\
\hline \multicolumn{10}{|c|}{ Winter } \\
\hline № -532903 & 38.2 & 62.6 & 27.4 & 38.7 & 63.3 & 29.2 & 39.0 & 63.1 & 28.5 \\
\hline № -656808 & 38.4 & 62.5 & 27.5 & 38.5 & 63.5 & 29.4 & 39.1 & 63.1 & 28.4 \\
\hline №-837122 & 38.5 & 62.7 & 27.5 & 38.0 & 63.7 & 29.3 & 39.0 & 63.3 & 28.6 \\
\hline \multicolumn{10}{|c|}{ Spring } \\
\hline № -532903 & 38.4 & 62.8 & 27.5 & 38.8 & 63.6 & 29.4 & 38.7 & 63.3 & 28.6 \\
\hline № -656808 & 38.6 & 62.7 & 27.4 & 38.6 & 63.7 & 29.6 & 38.6 & 63.2 & 28.6 \\
\hline №-837122 & 38.6 & 62.9 & 27.6 & 38.4 & 63.9 & 29.5 & 38.8 & 63.5 & 28.7 \\
\hline \multicolumn{10}{|c|}{ Summer } \\
\hline № -532903 & 39.1 & 63.0 & 31.3 & 39.4 & 63.4 & 32.8 & 39.1 & 63.5 & 31.8 \\
\hline № -656808 & 39.3 & 62.7 & 30.7 & 39.5 & 63.3 & 32.5 & 39.2 & 63.3 & 31.2 \\
\hline №-837122 & 39.4 & 63.0 & 30.8 & 39.5 & 63.5 & 32.6 & 39.3 & 63.6 & 31.2 \\
\hline \multicolumn{10}{|c|}{ Autumn } \\
\hline № -532903 & 39.1 & 63.0 & 31.3 & 39.4 & 63.4 & 32.8 & 39.1 & 63.5 & 31.8 \\
\hline № -656808 & 39.3 & 62.7 & 30.7 & 39.5 & 63.3 & 32.5 & 39.2 & 63.3 & 31.2 \\
\hline №-837122 & 39.4 & 63.0 & 30.8 & 39.5 & 63.5 & 32.6 & 39.3 & 63.6 & 31.2 \\
\hline
\end{tabular}


When the body temperature of mother goats was studied according to the seasons, it was observed that in the summer, the daytime temperature was $0.4-0.7{ }^{\circ} \mathrm{C}$ higher than the morning temperature, and in the evening, the air temperature decreased again. The body temperature of the mother goats averaged $39.2{ }^{\circ} \mathrm{C}$ per group in the summer, with an average of $38.8{ }^{\circ} \mathrm{C}$ in the spring, and it was observed that when air temperature increased, body temperature of female goat increased too. The respiratory rate of mother goat in the summer was on average 32.2-32.3 times/minute in the groups, respectively, whereas in the winter, spring and autumn, this figure was 32.3-32.8 times/minute, correspondingly (Table 2).

Table 2. Clinical indicators of mother goats $(p=5)$.

\begin{tabular}{|c|c|c|c|c|c|c|c|c|c|}
\hline \multirow{3}{*}{ 葛 } & \multicolumn{3}{|c|}{ Morning } & \multicolumn{3}{|c|}{ Afternoon } & \multicolumn{3}{|c|}{ Evening } \\
\hline & 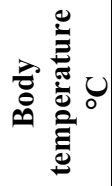 & 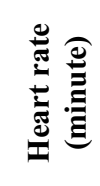 & 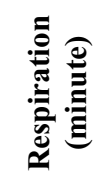 & U & 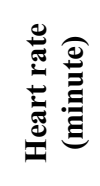 & 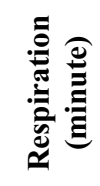 & ن & 营 & 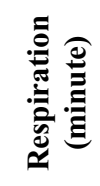 \\
\hline & $\mathrm{M} \pm \mathrm{m}$ & $\mathrm{M} \pm \mathrm{m}$ & $\mathrm{M} \pm \mathrm{m}$ & $\mathrm{M} \pm \mathrm{m}$ & $\mathrm{M} \pm \mathrm{m}$ & $\mathrm{M} \pm \mathrm{m}$ & $\mathrm{M} \pm \mathrm{m}$ & $\mathrm{M} \pm \mathrm{m}$ & $\mathrm{M} \pm \mathrm{m}$ \\
\hline \multicolumn{10}{|c|}{ Winter } \\
\hline I- & 38.7 & 69.36 & 28.53 & 39.43 & 78.53 & 32.33 & 38.53 & 71.73 & 31.63 \\
\hline II & 38.63 & 69.06 & 28.46 & 39.6 & 78.4 & 32.4 & 38.5 & 71.53 & 31.3 \\
\hline III & 38.6 & 69.16 & 28.33 & 39.36 & 78.3 & 32.2 & 38.46 & 71.53 & 31.5 \\
\hline \multicolumn{10}{|c|}{ Spring } \\
\hline I & 38.7 & 69.36 & 28.53 & 39.43 & 78.53 & 32.33 & 38.53 & 71.73 & 31.63 \\
\hline II & 38.63 & 69.06 & 28.46 & 39.6 & 78.4 & 32.4 & 38.5 & 71.53 & 31.3 \\
\hline III & 38.6 & 69.16 & 28.33 & 39.36 & 78.3 & 32.2 & 38.46 & 71.53 & 31.5 \\
\hline \multicolumn{10}{|c|}{ Summer } \\
\hline I & 38.8 & 69.46 & 28.63 & 39.43 & 78.60 & 32.40 & 38.56 & 72.43 & 31.66 \\
\hline II & 38.73 & 69.2 & 28.50 & 39.63 & 78.6 & 32.46 & 38.6 & 71.66 & 31.36 \\
\hline III & 38.7 & 69.3 & 28.40 & 39.4 & 78.4 & 32.26 & 38.50 & 71.66 & 31.5 \\
\hline \multicolumn{10}{|c|}{ Autumn } \\
\hline I & 38.53 & 69.46 & 28.60 & 39.43 & 78.50 & 32.36 & 38.43 & 72.33 & 31.60 \\
\hline II & 38.73 & 69.43 & 28.60 & 39.4 & 78.5 & 32.46 & 38.56 & 72.40 & 31.63 \\
\hline III & 38.7 & 69.3 & 28.40 & 39.46 & 78.4 & 32.26 & 38.50 & 71.56 & 31.56 \\
\hline
\end{tabular}


When the body temperature of young females was observed in the winter, spring, summer and autumn, in the summer, the daytime temperature was $0.4-0.7{ }^{\circ} \mathrm{C}$ higher than the morning temperature, and in the evening the air temperature decreased again. The body temperature of young females averaged $39.2{ }^{\circ} \mathrm{C}$ in groups in summer, $38.8^{\circ} \mathrm{C}$ in spring, $38.9^{\circ} \mathrm{C}$ in autumn, and $39.0^{\circ} \mathrm{C}$ in winter. Clinical cases of young goats were observed during the study. In the natural climate of Uzbekistan, changes in body temperature, heart rate and respiration were observed in goats imported in the morning, lunch and evening. Seasonal weather changes also had a positive effect on body temperature and heart rate. The average heart rate of goats in winter and spring was 69.1-69.26 times in the group I. In the summer, the heart rate averaged 78.4 beats per group and 78.33 beats in the fall, respectively. Respiratory rate in goats also increased, but it was at the level of physiological norm in young goats (Table 3 ).

Table 3. Clinical indicators of young goats $(p=5)$.

\begin{tabular}{|c|c|c|c|c|c|c|c|c|c|}
\hline \multirow{3}{*}{ 音 } & \multicolumn{3}{|c|}{ Morning } & \multicolumn{3}{|c|}{ Afternoon } & \multicolumn{3}{|c|}{ Evening } \\
\hline & 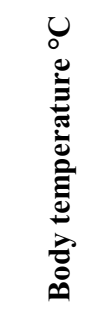 & 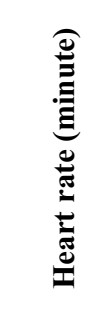 & 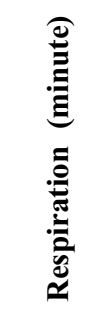 & 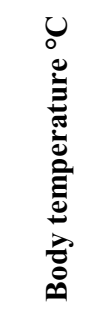 & 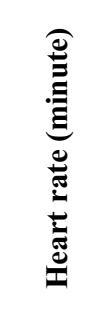 & 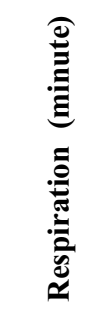 & 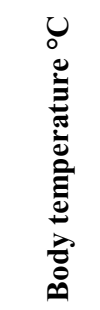 & 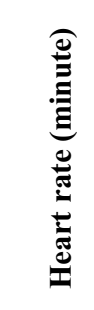 & 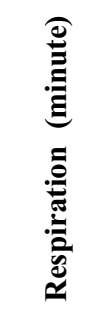 \\
\hline & $\mathrm{M} \pm \mathrm{m}$ & $\mathrm{M} \pm \mathrm{m}$ & $\mathrm{M} \pm \mathrm{m}$ & $\mathrm{M} \pm \mathrm{m}$ & $\mathrm{M} \pm \mathrm{m}$ & $\mathrm{M} \pm \mathrm{m}$ & $\mathrm{M} \pm \mathrm{m}$ & $\mathrm{M} \pm \mathrm{m}$ & $\mathrm{M} \pm \mathrm{m}$ \\
\hline \multicolumn{10}{|c|}{ Winter } \\
\hline I & 38.6 & 69.1 & 28.33 & 39.3 & 78.33 & 32.2 & 38.46 & 71.53 & 31.50 \\
\hline II & 38.46 & 68.93 & 28.20 & 39.4 & 78.3 & 31.86 & 38.36 & 71.36 & 31.1 \\
\hline III & 38.63 & 69.23 & 28.30 & 39.3 & 78.36 & 32.20 & 38.46 & 71.53 & 31.53 \\
\hline \multicolumn{10}{|c|}{ Spring } \\
\hline I & 38.6 & 69.1 & 28.33 & 39.3 & 78.33 & 32.2 & 38.46 & 71.53 & 31.50 \\
\hline II & 38.46 & 68.3 & 28.20 & 39.4 & 78.3 & 31.86 & 38.36 & 71.36 & 31.1 \\
\hline III & 38.63 & 69.0 & 28.30 & 39.3 & 78.36 & 32.20 & 38.46 & 71.53 & 31.53 \\
\hline \multicolumn{10}{|c|}{ Summer } \\
\hline I & 38.63 & 69.23 & 28.36 & 39.36 & 78.4 & 32.3 & 38.56 & 71.70 & 31.56 \\
\hline II & 38.53 & 69.03 & 28.33 & 39.43 & 78.3 & 31.93 & 38.40 & 71.43 & 31.13 \\
\hline III & 38.6 & 69.26 & 28.36 & 39.4 & 78.43 & 32.23 & 38.5 & 71.66 & 31.53 \\
\hline \multicolumn{10}{|c|}{ Autumn } \\
\hline $\mathrm{I}$ & 38.56 & 69.26 & 28.33 & 39.4 & 78.40 & 32.33 & 38.53 & 71.60 & 31.50 \\
\hline II & 38.5 & 68.96 & 28.33 & 39.26 & 78.2 & 31.9 & 38.56 & 72.40 & 31.63 \\
\hline III & 38.53 & 68.9 & 28.26 & 39.36 & 78.33 & 32.13 & 38.50 & 71.56 & 31.5 \\
\hline
\end{tabular}

When studying the hematological parameters of goat blood in the spring, their age, changes in the summer and autumn seasons, as well as feeding norms were taken into 
account and their correlation was observed. The average hemoglobin content in the blood of the study bucks was 9.67-9.73 g/percentage.

The indicators of increasing air temperature and increasing the body's exposure to the external environment were as follows. The number of erythrocytes in bucks, №-532903 was $8.83 \mathrm{ml} / \mathrm{mm}^{3}$, followed by $8.20 \mathrm{ml} / \mathrm{mm}^{3}$ in bucks №-656808 and $8.44 \mathrm{ml} / \mathrm{mm}^{3}$ in №837122. Furthermore, the number of leukocytes in the blood in the group № -532903 was 8.70 thousand $/ \mathrm{mm}^{3}$, it was 8.50 thousand $/ \mathrm{mm}^{3}$ in №-656808, and it was 8.60 thousand/mm3 in №-837122. The results of the study showed that in the winter and spring months, all blood counts in the heifers were physiologically normal (Table 4).

Table 4. The chemical composition of the blood of breeding bucks.

\begin{tabular}{|c|c|c|c|}
\hline Systems & $\begin{array}{c}\text { Hemoglobin, } \\
\mathrm{g} / \%\end{array}$ & Erythrocytes, $\mathrm{ml} / \mathrm{mm}^{3}$ & $\begin{array}{l}\text { Leukocytes, } \\
\text { thousand } / \mathbf{m m}^{3}\end{array}$ \\
\hline № -532903 & 9.73 & 8.83 & 8.70 \\
\hline №-656808 & 9.67 & 8.20 & 8.50 \\
\hline №-837122 & 9.69 & 8.44 & 8.60 \\
\hline
\end{tabular}

In the analysis of hematological parameters of the blood of mother goats, it was observed that the amount of hemoglobin was the same between the groups. In the spring months, an increase in air temperature and an increase in the body's exposure to the external environment was determined. No differences were observed between the groups in spring and autumn. The number of erythrocytes in the groups was $12.61-12.73 \mathrm{ml} / \mathrm{mm}^{3}$, or a high number of erythrocytes was observed in the spring due to an increase in natural pasture grasses in goat feed. The number of leukocytes in the body of mother goats was 9.02-10.04 thousand/ $\mathrm{mm}^{3}$, and hemoglobin was 9.85-10.87 g/percent. Evidently, leukocytes and hemoglobin in the blood of mother goats remained at physiological norm.

Table 5. Chemical parameters of mother goat blood $(p=5)$.

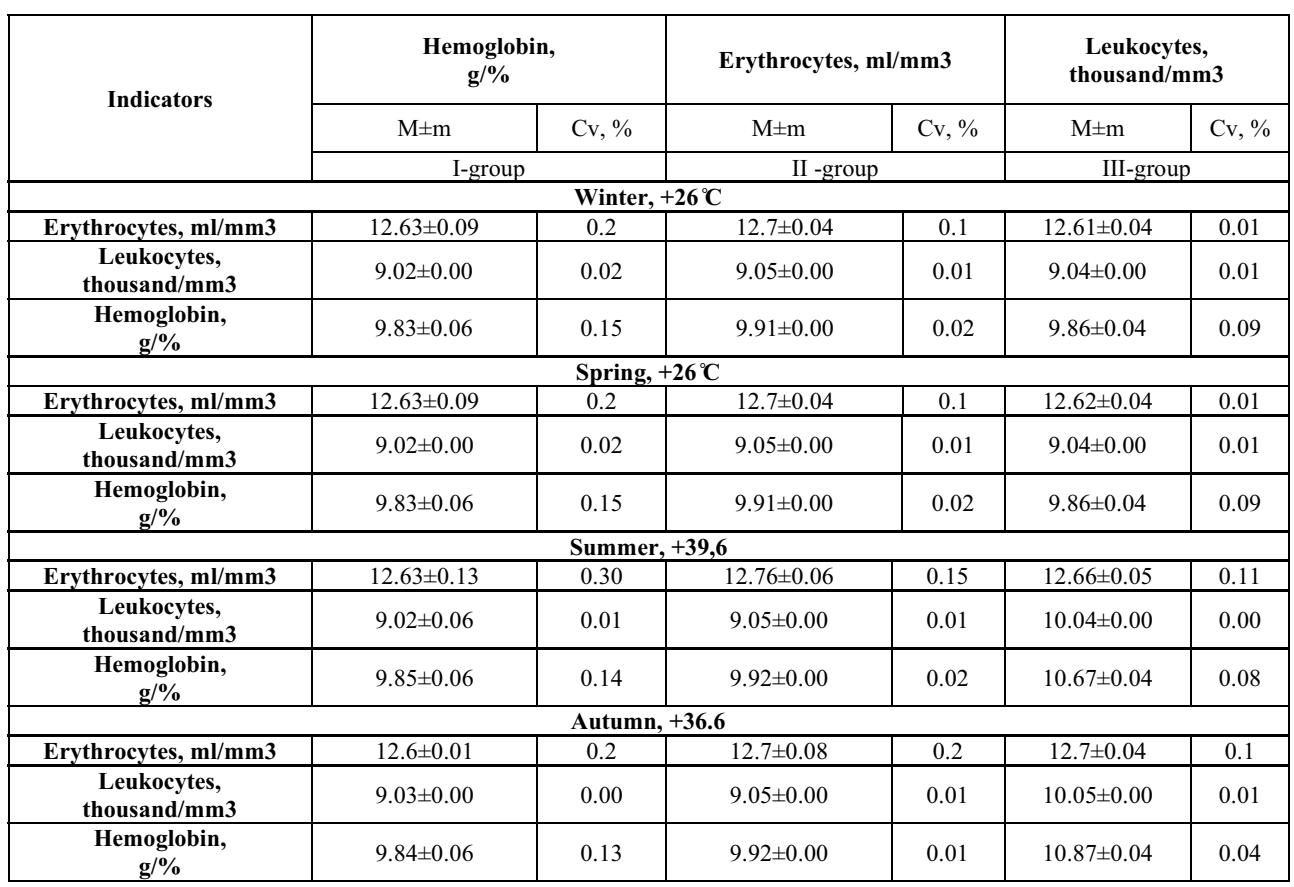




\section{Conclusions}

Clinical cases of young goats were observed during the study. In the natural climate of Uzbekistan, changes in body temperature, heart rate and respiration were observed in goats imported in the morning, lunch and evening. Seasonal weather changes also had a positive effect on body temperature and heart rate. The average heart rate of goats in winter and spring was 69.1-69.26 times in the group I. In the summer, the heart rate averaged 78.4 beats per group and 78.33 beats in the fall, respectively. Respiratory rate in goats also increased, but it was at the level of physiological norm in young goats. The average hemoglobin content in the blood of the study bucks was 9.67-9.73 g /percentage. The indicators of increasing air temperature and increasing the body's exposure to the external environment were as follows. The number of erythrocytes in bucks, №-532903 was 8.83 $\mathrm{ml} / \mathrm{mm}^{3}$, followed by $8.20 \mathrm{ml} / \mathrm{mm}^{3}$ in bucks №-656808 and $8.44 \mathrm{ml} / \mathrm{mm}^{3}$ in №-837122. Furthermore, the number of leukocytes in the blood in the group № -532903 was 8.70 thousand $/ \mathrm{mm}^{3}$, it was 8.50 thousand $/ \mathrm{mm}^{3}$ in №-656808, and it was 8.60 thousand $/ \mathrm{mm} 3$ in №-837122. The results of the study showed that in the winter and spring months, all blood counts in the heifers were physiologically normal.

The change of seasons in the natural climate of Uzbekistan for imported goats does not adversely affect the morphology and clinical parameters of the blood, especially breeding heifers, mother goats and young goats, and their physiological condition remains normal. In order to effectively use the imported breed of goats in breeding, it is necessary to create new dairy farms, first of all, to maintain their population, care and feeding of young goats in accordance with the technologies used in milking goats, proper use of dairy goats in milking and adoption of goats.

\section{References}

1. President Decree No. 4947 of the Republic of Uzbekistan on "the Action Strategy for the five priority areas of further development of the Republic of Uzbekistan for 20172021 ”, on Feburary 7 (2017)

2. M. Ismailov, Zooveterinary, 6 (2016)

3. M. Ismoilov, Zooveterinariya, 7 (2017)

4. A. Mysyk, Zootechniya, 10 (2008)

5. S. Novopashina, M. Sannikov, T. Kozhanov, Sheep, goat, wool business journal, 3, 11 (2014)

6. S. Novopashina, M. Sannikov, V. Kulinich, E. Kizilova, I. Kondrashina, Sheep, goat, wool business journal, 4, 7 (2015)

7. I. Eshmatov, Zooveterinariya, 3 (2017)

8. I. Eshmatov, III International Scientific and Practical conference on "animal husbandry", 18-24 (2019)

9. B. Akhmedov, Theoretical \& Applied Science, 3, 9 (2019)

10. B. Henry, R. Eckard, K. Beauchemin, Animal, 12, 144-151 (2018)

11. F. Yousuf, A. Apu, K. Talukder, M. Ali, S. Husain, Journal of the Bangladesh Agricultural University, 18, 2 (2020)

12. G. Msalya, Z. Nziku, T. Gondwe, G. Kifaro, L. Eik, T. Ådnøy, In Climate Impacts on Agricultural and Natural Resource Sustainability in Africa, Springer, 10 (2020).

13. O. Bykova, O. Loretts, I. Donnik, O. Neverova, M. Barashkin, V. Krasheninnikova, Research Journal of Pharmaceutical, Biological and Chemical Sciences, 9, 5 (2018) 